\title{
TRAVELLING WITH DARWIN AND HUMBOLDT. A TRANSDISCIPLINARY EDUCATIONAL EXPERIENCE
}

\author{
YOLANDA ECHEGOYEN-SANZ \\ Experimental and Social Sciences Didactics Department, University of Valencia \\ Avda. Tarongers $n^{\circ} 4,46022$, Valencia \\ E-mail address: yoesanz@uv.es \\ ORCID number: 0000-0002-3729-460X
}

ANTONIO MARTÍN EZPELETA

Language and Literature Didactics Department, University of Valencia

Avda. Tarongers $\mathrm{n}^{\circ} 4,46022$, Valencia

E-mail address: anmarez@uv.es

ORCID number: 0000-0003-0210-3399

\begin{abstract}
Aim. This research aims to confirm that transdisciplinary projects can be very adequate to develop content and competencies traditionally assigned to Sciences and Arts in higher education, exploring the possibilities of outdoor education.

Methods. The subjects of the study were one hundred alumni of two different courses "Natural Sciences for Teachers" and "Literary Training for Teachers" at a Spanish university. An educational experience around the phenomenon of scientific travelers was developed, focusing on Charles Darwin and Alexander von Humboldt and the literary genres of travel journals and letters. The main activity contained three phases, including indoor and outdoor education, in which both subjects tackled the same 6 educational topics from a different perspective. After different individual and group activities around those topics, alumni from both subjects merged at a natural environment where a scientific-literary tour took place. At the end of the academic year, an assessment questionnaire with open and closed questions was filled out by all participants.

Results and conclusion. After the analysis of all the collected data, we can deduce that the experience was a success. The students appreciated aspects like the setting in which the experience took place, the possibility of interacting with alumni from different courses and the integration of Sciences and Arts. Thus, we have demonstrated that the same activities can be implemented in prototypical subjects of Sciences and Arts and that outdoor education is an ideal resource to achieve a holistic pedagogy engaging the sensory and emotional facets of learning.

Key words: transdisciplinarity, outdoor education, emotional learning, scientific travelers, preservice teachers
\end{abstract}




\section{THE IMPORTANCE OF TRANSDISCIPLINARY EDUCATION}

$\mathrm{T}$ The term transdisciplinarity was coined at the first international conference on interdisciplinary research and education in the early 1970s. At that time, there were two different ideas about it. On the one hand, Jean Piaget believed that the maturation of general structures and fundamental patterns of thought across fields would lead to a general theory of systems or structures. On the other hand, Erich Jantsch envisioned a multi-level systemic coordination of research, innovation, and education. However, they both agreed that transdisciplinarity was "still a dream" (Apostel, 1972, p. 138)

In the following decades, the use of the term broadened and is now related to different disciplines (i.e. Geography, Philosophy and Religious Studies), comprehensive paradigms (i.e. Feminism, Marxism) or broad interdisciplinary fields (i.e. Cultural Studies) (Thompson Klein, 2004). Since the last decade of the $20^{\text {th }}$ century, transdisciplinarity aimed at solving global concerns, like climate change or sustainability, and in areas concerning Science, Technology, Social Problems and Policy, Education, and the Arts (Bernstein, 2015). In his Manifesto of Transdisciplinarity, Barasab Nicolescu (2002) explains that the transdisciplinary vision replaces reduction with a new principle of relativity, is transcultural, transnational, and encompasses ethics, spirituality, and creativity. According to this author, it is not a new discipline or superdiscipline, but the science and art of discovering bridges between different areas of knowledge and different beings.

One of these bridges, connecting Sciences and Humanities, can be found in Environmental Humanities. This is an interdisciplinary area of research inside the Humanities that has grown in the last decades, with many environmental sub-disciplines like Environmental Literature, Environmental Philosophy, Environmental History or Environmental Anthropology. It is clear that responses to environmental problems are primarily social and cultural issues (Kueffer, Forêt, Hall, Wiedmer, 2018) and a change in our ways of thinking is needed. It has also been demonstrated that environmental literature can be used as a didactic resource to raise awareness about environmental and sustainability problems (Martín-Ezpeleta, EchegoyenSanz, 2017, 2018).

In the case of Spain, there is a need for curricular changes to integrate Experimental Sciences and Humanities, as well as the epistemological development of an environmental competence, and even the impulse of environmental classrooms and the design of didactic materials aimed at different educational levels as Àngels Ull, Albert Piñero, Ma Pilar Martínez Agut and Pilar Aznar Minguet (2014) and Amparo Vilches Peña and Daniel Gil Pérez (2015) have established. The following study also underlines the need for teachers to prepare materials facing the environmental education of the $21^{\text {st }}$ century. It is crucial for pre-service teachers to experience an educational approach integrating Sciences and Arts because once they became in-service teachers, they will have to integrate very heterogeneous content and competences in their Pri- 
mary Education classes, which are not as tightly compartmealised in subjects and specialties as in Secondary or Higher Education.

The innovative educational project "Sciences and Arts" at the University of Valencia has the goal to design didactic materials inspired with the integration of Sciences and Arts as well as explore their educational possibilities with pre-service teachers. Different phenomena such as feminism, environmental problems, knowledge transfer, science fiction or scientific travelers have been addressed. The idea is that the work at a Science classroom can be based on literary texts and that scientific content and reflection on environmental protection are not incompatible with Literature lessons (The thorough explication of the project "Sciences and Arts", as well as the generated didactic materials can be consulted at the web page: <www.uv.es/ciencylet>).

As Freirean pedagogy postulates, a change in the educational system is needed to renew the processes of teaching and learning (Freire, 2018). This is basically incompatible with an inflexible, tight and curricular system based on monographic studies and aligned with a horizontal and interdisciplinary knowledge. Our ultimate goal with the activities proposed is to promote the knowledge of students in relevant subjects such as Language, Literature or Science, but always mixing together knowledge from the different areas and subjecting them to a holistic, real and ethical training, including aspects related to ecology and environmental protection, but also civic responsibility or empathy.

\section{OUTDOOR AND EMOTIONAL LEARNING}

One alternative to traditional education that has been proved to increase student motivation is education outside the classroom (Bølling, Otte, Elsborg, Nielsen, Bentsen., 2018). It consists of relocating some of the curricular activities to places outside the school (Becker, Lauterbach, Spengler, Dettweiler, Mess, 2017; Waite, Bølling, Bentsen, 2016). These locations could be close to the school (i.e. parks) or not so close (i.e. museums, factories or forests), although normally the activities are conducted in nature and green places (Bentsen, Schipperijn, Jensen, 2013). The activities are often led by students using collaborative work with the purpose to obtain concrete and personal experiences (Waite, 2011). Although this type of education is normally used in Primary and Secondary Schools it could also be a good resource in Higher Education.

Outdoor experiences have a great potential for ecological and sustainability focused learning, as examples in North America (O'Connell, Potter, Curthoys, Dyment, Cuthbertson, 2005), Denmark (Andkjær, 2012) or United Kingdom (Higgins, 2009) show. Allen Hill (2013) argues, however, that learning experiences in remote pristine environments can have a variety of outcomes and not all of these experiences necessarily lead to the development of attitudes, understanding, skills, and motivation to live more sustainably. He indicates that ignoring more local places could present a dichotomous view of nature to students, thereby disrupting efforts to educate for sustainability. For this 
reason, we decided to set our experience in a natural environment inside the city of Valencia.

On the other hand, it is well known that in higher education, apart from cognitive factors, motivation and emotion significantly influence educational outcomes (Bruinsma, 2004). According to modern Biology, humans are fundamentally emotional and social creatures and the high-level of cognitive skills taught in schools (reasoning, decision making, etc.) do not function as rational, disembodied systems detached from emotion and the body. A good teacher knows that emotions, feelings or the state of the body affect students' performance and learning but recent research (Immordino-Yang, Damasio, 2007) states that the relationship between learning, emotion and body state is interwoven with the notion of learning itself.

Different studies have focused on how emotions influence the cognitive information processing and the quality of thinking (Meyer, Turner, 2002; Wolters, Pintrich, 1998; Kuyper, Werf, Lubbers, 2010): positive emotions facilitate learning and performance while intense negative emotions interfere with learning and contribute to lower performance. According to Reinhard Pekrun, Thomas Goetz, Wolfram Tits and Raymond Perry (2002) positive emotions such as enjoyment, hope, and pride lead to high achievement. The study also indicated that these emotions were also related to students' cognitive resources, learning strategies, motivation and self-regulation. In this sense, experience-based learning, which according to Roy Ballantyne and Jan Packer (2009) includes "learning by doing", " being in the environment", "real life learning", "sensory engagement" and "local context", is also particularly important in addressing students' environmental attitudes and actions.

In this context, we present here the outcome of a didactic proposal in which outdoor, experiential and emotional learning were present. One of the prepared activities was located in a natural environment very close to the students, the Botanical Garden of the University of Valencia, with the idea that it is a place that will leave a mark and they could revisit easily, favoring in this manner a meaningful learning.

\section{DIDACTIC PROPOSAL}

For this proposal, we selected the phenomenon of scientific travelers and addressed it from a double perspective: the knowledge of the most relevant scientific travelers and the literary genres of travel journals and letters. Charles Darwin and his Voyage of the Beagle around the world between 1831 and 1836, that ultimately led the author to publish his Theory of Evolution, as well as Alexander von Humboldt and the exploration of America between 1799 and 1804 were the two scholars that we focused mainly on. We also brought up the visit of Alexander von Humboldt to the city of Valencia, explained in his diaries, and his epistolary relationship with the Valencian botanist Antonio José de Cavanilles. 
The key of the didactic activities prepared around scientific travelers is that they were implemented at the same time in prototypical subjects of Sciences and Arts at the Faculty of Teaching of the University of Valencia, such as "Natural Sciences for Teachers" and "Literary Training for Teachers". Both are compulsory subjects, taught in the sophomore year of Bachelor degrees in Early Childhood Education and Primary Education.

\section{OBJECTIVES}

The main objectives of the didactic proposal are:

1) To use scientific travelers to work together (autonomously and collaboratively) contents and competencies traditionally related to Sciences and Arts in typical subjects of both disciplines.

2) To design transdisciplinary didactic materials for children around the topic of travelling and discovery.

3) To use outdoor learning by carrying out a scientific-literary tour through the Botanical Garden with alumni from two courses. There, a selection of the main conclusions and prepared didactic materials were shown, achieving significant and peer learning.

4) To develop transversal competences such as gender equality or communicative competences.

5) To use experiential learning, engaging the students in activities designed to train the needed socially responsible and pro-environment teachers of the future.

\section{METHODOLOGY}

Phenomenon-based learning methodology (Symeonidis, Schwarz, 2016) with the influence of Cultural Studies, whose purpose is to train responsible citizens, as proposes Henri Giroux (2004) was used to integrate Experimental Sciences and Arts in teacher education. This approach advocates integrating the knowledge and skills of many diverse disciplines around a key phenomenon. For example, climate change is not only studied from the Physics, Biology, Economy or Ecology points of view but also from Literature, Cinema or History. Based on this, we specify a series of methodological aspects:

1) The selected phenomenon is scientific travelers, which is in this proposal associated with others like climate change, biodiversity loss, travel journals, letters or, among others, recognition of the role of women.

2) All the activities/tasks integrated at the same time content and competences traditionally assigned to Sciences or Arts.

3) Collaborative learning and creativity are strongly promoted, integrating the use of ICTs.

4) Transversal competences like communicative competence, environmental protection or gender equality are also addressed. 


\section{PREPARED ACTIVITIES}

Different activities, which combined autonomous and collaborative work, were implemented with different groups of the two subjects around the phenomenon of scientific travelers. The students of "Natural Sciences for teachers" had to create an exposition for children after reading Charles Darwin's "A naturalist voyage around the world." Each group (3 or 4 students) read the chapter and prepared a poster of one of the voyage stops (15 posters in total) and had to extract a short fragment that they considered relevant as well as include information about flora, fauna, geology or climate of the region. Each poster had to include some didactic activities for the children supposedly attending the exposition.

Another activity for students of "Natural Sciences for teachers" used Humboldt as an excuse to work around climate change and the effect of humans on different natural environments. The students read Humboldt's letter to his brother about his climbing of the Chimborazo volcano in Peru, and compared his drawings of the site with a similar image published by a Spanish periodical journal after some Scientifics repeated the climbing of the Chimborazo volcano in 2012 and reported, as Humboldt did, about the flora they found at each altitude.

The students of "Literary training for teachers" studied biographical literature from travel journals (some of them by scientists) and letters written by Charles Darwin, Alexander von Humboldt or Christopher Columbus. They also read an ecocritical novel Instrucciones para salvar el mundo [Instructions to save the world] by Rosa Montero. In that book there were reflections about the sustainability of the planet with basic technical notions of Physics or Ecology around a plot about depression and middle-age problems.

However, the final activity consisted of a scientific-literary tour at the Botanical Garden of the University of Valencia during which alumni from the both subjects cooperated. It was a conjunction of the above-mentioned activities and the final project is explained in detail in the next section.

\section{SCIENTIFIC-LITERARY TOUR}

The main activity of those around scientific travelers was a scientific-literary tour organized in the Botanical Garden of the University of Valencia. The site was selected because, in addition to being a symbolic place of the city and very beautiful, as explained earlier, it is well established that the nexus of experience and place offers significant promise for educational endeavor (Hill, 2013). This learning experience was aimed at utilising a holistic pedagogy engaging kinesthetic/physical, sensory, and emotional facets of learning, as well as cognitive. One hundred alumni of two subjects "Literary Training for Teachers" and "Natural Sciences for Teachers" participated. Each stop of the tour contained a common educational synthesis, which the students of both subjects tackled in different ways. 
The work was designed as jigsaw classroom (Aronson, 2002) in which each group was an expert on one topic and explained it to the rest in two phases: first in a short exposition in the classroom to their classmates and then on a scientific-literary tour that both groups attended together at the Botanical Garden of the University of Valencia. The first exposition was arranged so that the whole group could take advantage of the work of the companions and served as a general rehearsal for the exposition that would take place on the aforementioned scientific-literary tour. Each class was divided into twelve groups, in such a way that each topic was studied by two groups.

\section{First stage. In the classroom with their classmates}

In the first place, a collaborative work with a duration of five classroom sessions took place, although there was also autonomous work outside the classroom. In this stage the students had to train in scientific and literary aspects at the same time. It was a project of the whole group composed of tasks carried out by small random groups of up to four students, who studied multidisciplinary documentation and materials provided by the teachers and organised around six scientific-literary topics.

These topics covered different educational dimensions related to the phenomenon of scientific travelers. As shown in Table 1, they were materialised in two types of analysis, one from a more literary than scientific point of view, and another, from a more scientific than literary point of view that sought to be complementary and helped to reach the educational synthesis.

Table 1.

Educational synthesis and topics for both subjects.

\begin{tabular}{|c|c|c|}
\hline Educational synthesis & $\begin{array}{c}\text { "Natural Sciences for } \\
\text { Teachers" }\end{array}$ & "Literary Training for Teachers" \\
\hline $\begin{array}{c}\text { Travelling as a personal } \\
\text { and professional } \\
\text { training }\end{array}$ & $\begin{array}{c}\text { The great scientific } \\
\text { expeditions. Humboldt's } \\
\text { journey }\end{array}$ & $\begin{array}{c}\text { Scientific travelers in their letters. } \\
\text { Alexander von Humboldt }\end{array}$ \\
\hline $\begin{array}{c}\text { The culture of flowers } \\
\text { Darwin's flower }\end{array}$ & $\begin{array}{c}\text { The flowers of reason. Rubén } \\
\text { Dario's roses }\end{array}$ \\
\hline $\begin{array}{c}\text { Literature as a travelling } \\
\text { companion }\end{array}$ & $\begin{array}{c}\text { The discovery of pineapple } \\
\text { (and other foods) in the } \\
\text { Indian chronicles }\end{array}$ & $\begin{array}{c}\text { Diaries and chronicles of } \\
\text { Christopher Columbus and } \\
\text { Washington Irving, a round trip }\end{array}$ \\
\hline $\begin{array}{c}\text { The recognition of } \\
\text { professional women }\end{array}$ & $\begin{array}{c}\text { The quiet voice of women } \\
\text { The quiet voice of women. María } \\
\text { Cegarra Salcedo }\end{array}$ \\
\hline $\begin{array}{c}\text { Environmental } \\
\text { protection }\end{array}$ & $\begin{array}{c}\text { Environmental humanities } \\
\text { for children }\end{array}$ & $\begin{array}{c}\text { Ecocriticism for children. The stories } \\
\text { of Jen Green and Mike Gordon on } \\
\text { environmental education }\end{array}$ \\
\hline The beauty of nature & The natural beauty & $\begin{array}{c}\text { Writers who were scientists and } \\
\text { scientists who wrote. The aphoristic } \\
\text { literature of Wolfgang von Goethe } \\
\text { and Jorge Wagensberg }\end{array}$ \\
\hline
\end{tabular}

Source: Own elaboration 
Academic texts from the fields of Natural Sciences, Philology or Literature Didactics and Experimental Sciences Didactics, as well as articles published in specific journals, book chapters and even doctoral theses were used as bibliographical references and materials of each topic in the different subjects. Also, the reading of popular science texts, published for the most part in the periodical press, was promoted.

In both subjects the six topics were studied by two different groups. The work had three phases: firstly, the topics in question had to be assimilated from the provided bibliographical references and texts and any other material that the students considered interesting or relevant. The professors were in charge of making sure that the documents were understood by the students during the face-to-face sessions. Then the students had to prepare a brief presentation (around 10 minutes) that would explain their topic to their classmates. Finally, they had to make a didactic transposition (Chevallard, 1991) of what they had learned, by designing some didactic activities for children. The prepared activities for children presented the studied topics from the perspectives of Geography, Literature, Art, Sustainability, etc., showing how the didactic transposition was done also in a transdisciplinary manner.

\section{Second stage. Collaboration of the students at the Botanical Garden}

The scientific-literary tour of students attending both courses took place at the Botanical Garden of the University of Valencia. It was founded in 1567 although its current location was definitively established in 1802. During the 20th century, it fell into disrepair for a long time until, in 1987, the University of Valencia began the process of fully restoring it, which concluded in the year 2000. Currently, the Garden extends over approximately 4 hectares and carries out research into plant diversity, conservation of rare, endemic or endangered species of Mediterranean flora and the conservation of natural habitats.

The tour around the Botanical Garden was designed in such a way that each topic was related to a particular place inside the Garden (i.e., "Darwin's flower" was explained at the greenhouse where the actual orchid grows, the educational synthesis "Natural beauty" was explained at a photography exhibition that was being presented at the time, the topics about Christopher Columbus and the American discovery were explained at the tropical plants greenhouse, etc.).

As mentioned, each topic was prepared by two groups of students with the objective that the six educative syntheses with both perspectives were listened to by all students. The scientific-literary tour was carried out twice. Half of each group of "Literary Training for Teachers" and "Natural Sciences for Teachers" attended the scientific-literary tour each day so that classes and disciplines were mixed up with an adequate number of students to carry out the experience. The objective was to cross the expositions that had been prepared in the context of different disciplines and with different biases, to invite students to delve into the scientific-literary issues from different and complementary perspectives, but also to experience the benefits of transdisciplinary projects. 
The intervention of each group of students had three parts: reading of a text of their choosing related to their topic (some read a poem, others a letter, a fragment of a novel...); a short exposition of the topic they had worked on; and explaining in detail one of the didactic activities aimed at Primary Education children from the three or four they had prepared, showing some materials (texts, images, stories, objects, etc.).

Although the starting materials were the same, the perspective for each topic was different even between the two groups in the same subject showing how previous experiences influence the learning experience. For example, the selected texts for the topic "Natural beauty" at "Natural Sciences for Teachers" were Federico García Lorca's poem about rain and an opinion article of a Physics professor about the beauty of Science.

Two strategies were followed to dynamise the activity: a diary of the tour where the students could show their impressions and opinions which was written voluntarily during the itinerary and a Twitter contest (@ciencylet, \#cienciasyletrasNaturalmente [\#sciencesandartsNaturally]) which took place to select the best picture. Some of the diary entries and pictures for the contest are shown in Figure 1. The participation in both initiatives was high and the diary entries ("we are having an amazing time!"; "I like very much to do new things and get outside the classroom"), as well as the tweets that accompanied the pictures showed how the students valued the experience and were engaged by this educational proposal.

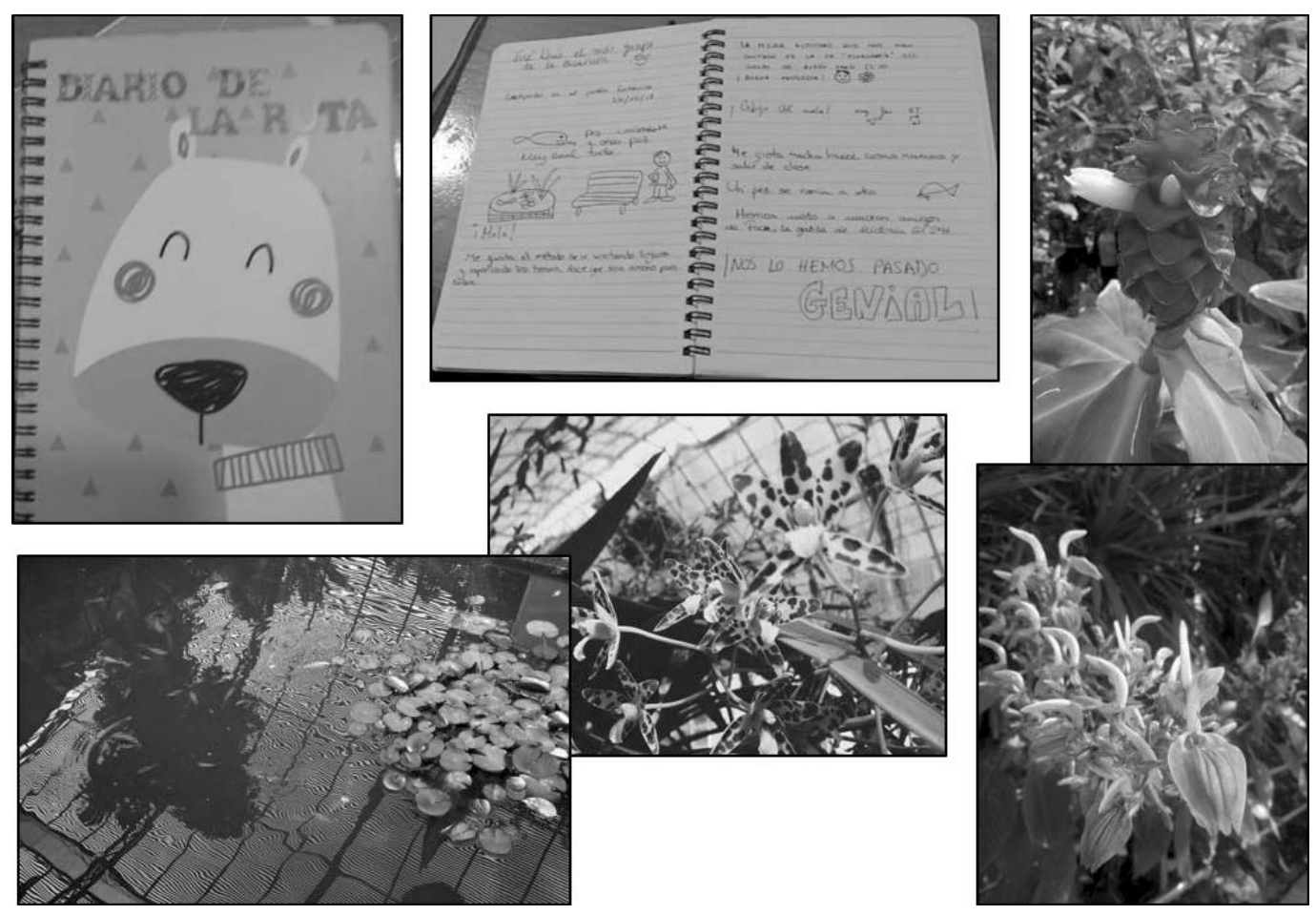

Figure 1.

The tour diary and some of the pictures for the contest.

Source: Twitter (\#cienciasyletrasNaturalmente) and own pictures 


\section{THIRD STAGE. INDIVIDUAL REFLECTION.}

According to David Kolb's (1984) experiential learning model, in the learning cycle there is a need for reflective observation reviewing what has been done and experienced. To facilitate this task, the final assignment to the alumni was the writing of a paper in which they reflected on the different aspects of the experience: the integration of Sciences and Arts, outdoor education, didactic transposition, the interaction between alumni from both subjects, etc., as well as include an autoevaluation and coevaluation of the work group.

The reflection of the students about the experience had, in most cases, a positive feedback. Here we present some fragments: "After preparing, with great enthusiasm, the exposition, the activities and their materials the big day of the excursion to the Botanical Garden arrived. Just before entering we were informed of the hashtag that had to be used and I was excited by the idea, since two of the things that I liked doing the most were united: flowers and nature with photography (A.M.)"; "When we got there, we met with the group of students in the "Literary Training" class, the main idea was to show our projects, since they were related to each other, but treated from the scientific and literary point of view. This is a very enriching practice, since both contents complemented each other and gave rise to a more complete sense of what was being explained (V.O.)"; "With this visit it was shown how Literature and Sciences are transversal instruments through which the learning of concepts and processes belonging to these two disciplines can be promoted and facilitated. Literature can bring science to students who are not so interested in it or the reverse process can happen, that through science a student will discover the world of literature and see how related they are to each other (I.J.)"; "Regarding the visit to the Botanical Garden, just the fact of being there is already an experience that awakens the five senses. The aromas, the colorfulness of some plants and the strategic stops for the realisation of the exchange of ideas is a gift for any student, helping to enrich their knowledge by facilitating their assimilation, and is the protagonist at all times. It has been an experience that I completely recommend, and that in the future as a teacher I will take into account in the planning of the activities carried out by the students (I.R.)"; or "At the tour it was very enjoyable to go walking through the Botanical Garden and alternate the places of explanation, because we could travel to a lot of spaces that, in one way or another, were related to the expositions, such as Darwin's flower (I.F.)".

\section{ANALYSIS OF THE FINAL QUESTIONNAIRE}

At the end of the academic year a final questionnaire about this educational proposal was filled out anonymously by 84 of the participants. It contained open and closed questions and delved into the practical and emotional facets of the experience, as well as different aspects of transdisciplinarity in education. 
The students were asked to select their favourite activity of the semester and $82.4 \%$ selected the scientific-literary tour at the Botanical Garden. When asked about which aspect of this particular didactic proposal they valued the most (see Figure 2), 84.5\% selected the exposition at the Botanical Garden, 9.5\% selected the exposition in the classroom and $6 \%$ the reflective essay that they had to write after the experience.

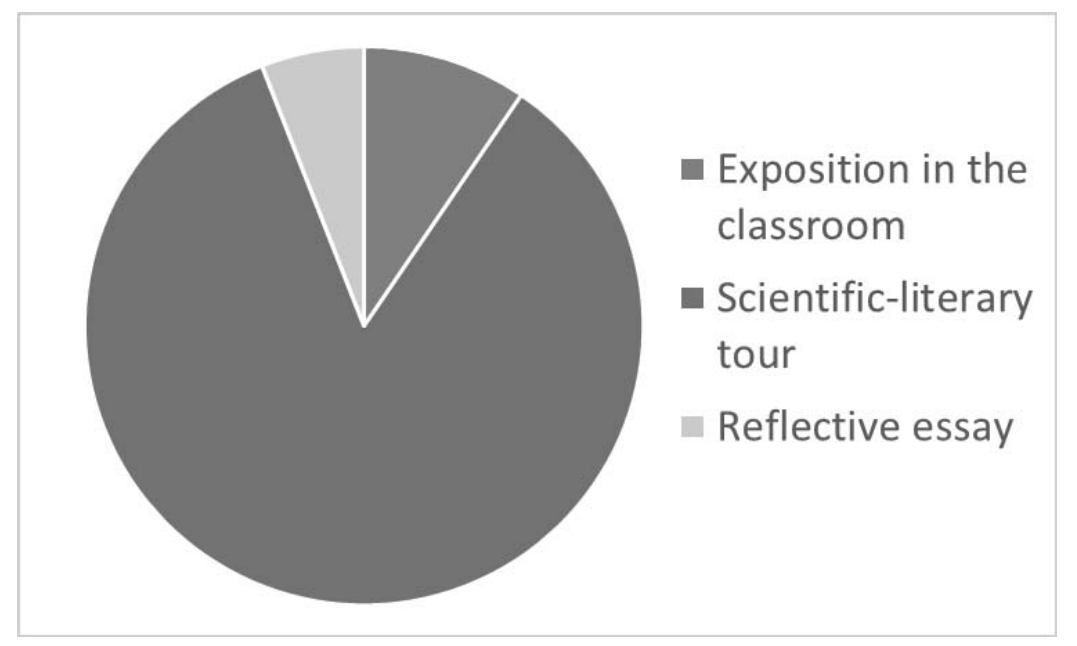

Figure 2.

Responses to the question: "Which was your favourite activity of the didactic proposal?"

Source: Own elaboration

As for the most emotional moment for them during the scientific-literary tour, the responses are shown in Figure 3. For the majority of the students the expositions were the part of the experience that moved them the most, either in general (23.8\%), their own exposition (40.5\%) or the exposition of their topic by the group from the other subject $(35.7 \%)$. Aspects very valued were also different parts of nature: the greenhouses that we visited, trees, plants, especially the carnivorous plants that really impacted them, the coffee and cacao plants, etc. (e.g., "The observation of the plants with their aesthetics and aromas, because we left a closed building to be able to verify by the experience and the senses and from nature, the contents"). Also the Botanical Garden as the setting of the experience (e.g., "When we saw the entrance for the first time, where we could observe the beauty of that garden", or "Honestly, it was as soon as we entered. Seeing so many plants, with that green thickness, to breathe there... I don't know, it provoked a feeling of freedom that you cannot often experience in the city"). Some of the students even declared that they were planning to visit the Botanical Garden again in the future. 


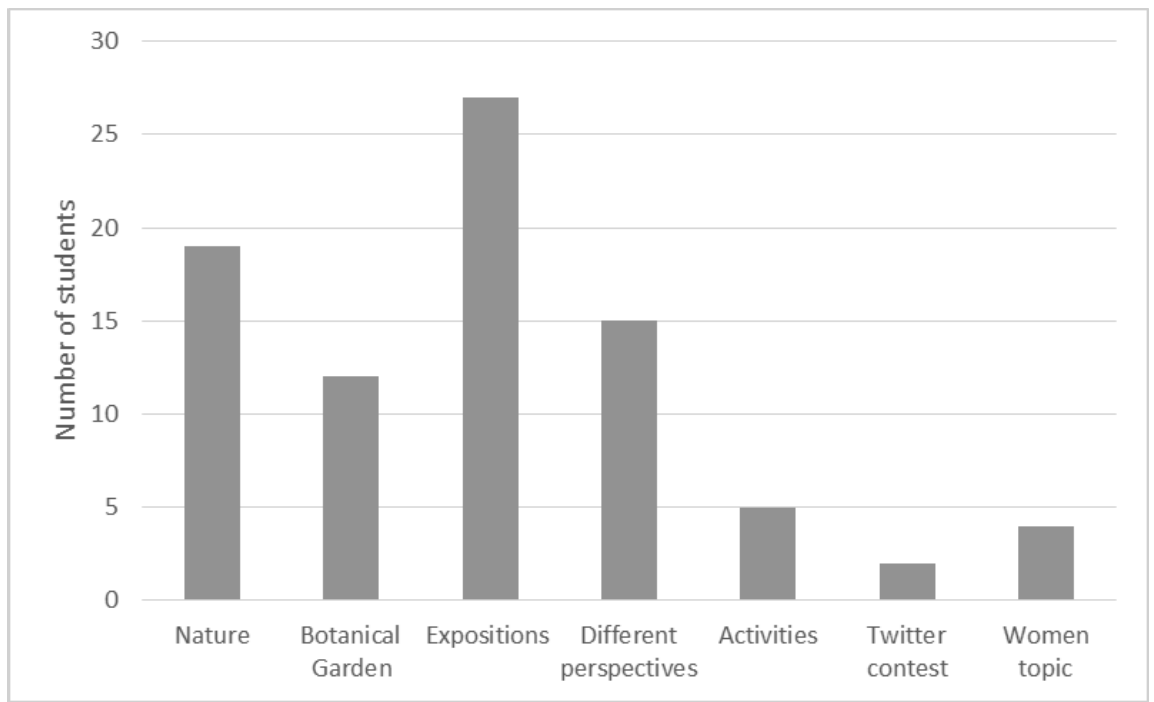

Figure 3.

Aspects at the scientific-literary tour that moved the students.

Source: Own elaboration.

The fact of being able to see different perspectives of the same topic by attending the expositions and activities of the alumni from the other subject was also selected by the students as one of the most moving factors of the experience, so the integration of Sciences and Arts was really successful. And some students also highlighted emotional aspects when they saw the activities for children explained by other groups, the photographic Twitter contest or the fact of including the genre perspective as one of the topics.

We also asked explicitly about the importance of integrating Sciences and Arts in education and most of the students consider it very $(54.9 \%)$ or quite $(42.7 \%)$ important (see Figure 4 ).

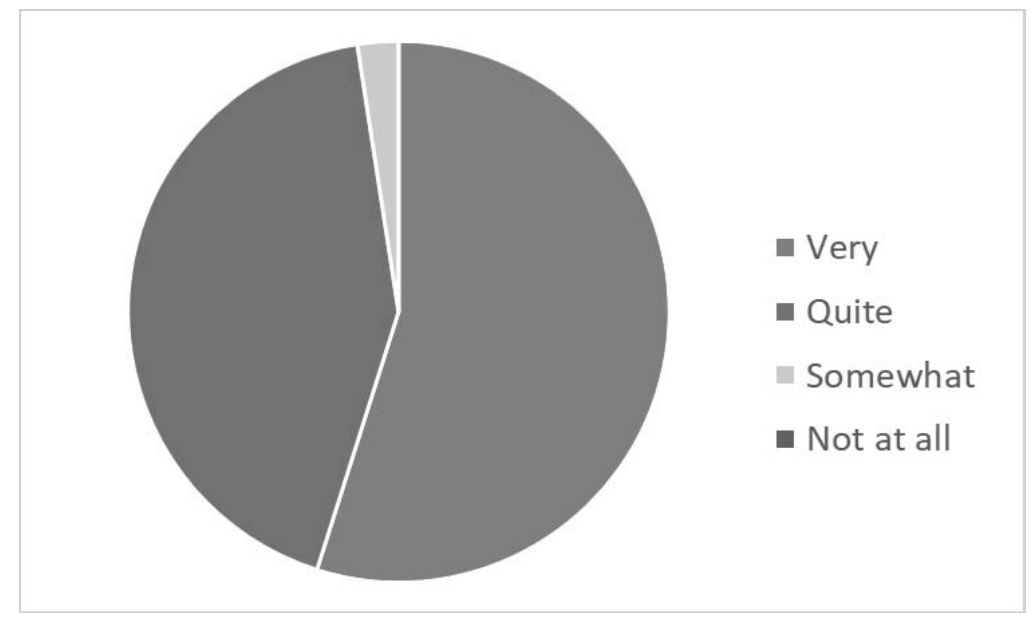

\section{Figure 4.}

Responses to the question: "Do you think it is important to integrate Sciences and Arts?"

Source: Own elaboration 
Some of the arguments in favour of this integration were: "It is favorable for students to learn globally and not having unconnected parts that end up being forgotten with time if they have nothing to do with anything other than the exam," or "Because uniting both a better understanding of certain topics is achieved, and a much broader knowledge acquisition, since they work on different subjects at the same time." But our students go even further and propose to integrate many other branches of knowledge: "Yes, and not only with literature, sciences must also relate to art, or sports, in order to facilitate the relationships that have been discussed before and that favor meaningful learning. In addition, they help to understand the importance of all subjects, not arriving at the sterile conclusion that the sciences are the best or more useful discipline, etc.," or "Yes, but not only between sciences and arts but between all the branches of knowledge, since it is demonstrated that the interrelation of content between the different subjects promotes and improves the quality of learning."

\section{CONCLUSIONS}

We have been able to integrate content and competences of different disciplines in activities like the ones detailed here about scientific travelers. In addition, we highlighted two key figures in the History of Science as Charles Darwin and Alexander von Humboldt (this last unknown by most of the students).

The use of a natural environment like the Botanical Garden as the setting for the scientific-literary tour, exploring the possibilities of outdoor education with higher education students, was a success and one of the key aspects highlighted by the students in both the reflective essay and final questionnaire. They also valued the possibility to be in contact with students from other groups, the integration of Sciences and Arts and the reflection that entailed, and the use of Twitter to dynamise the activity.

We propose that these phenomena and didactic activities can structure the official educational curricula in the future, in contrast to the general rule of organisation in separate scientific disciplines. The integration of content and competences in proposals like the one shown here about scientific travelers will stimulate the empathy, curiosity and motivation of the students offering a holistic, real and ethical education. This is not a new approach, but it has still not reached the dominant educational system.

\section{REFERENCES}

1. Andkjær, S. (2012). A Cultural and Comparative Perspective on Outdoor Education in New Zealand and Friluftsliv in Denmark. Journal of Adventure Education \& Outdoor Learning, 12(2), 121-136. doi: 10.1080/14729679.2011.643146

2. Apostel, L. (1972). Interdisciplinarity Problems of Teaching and Research in Universities. Paris: OECD. 
3. Aronson, E. (2002). Building Empathy, Compassion, and Achievement in the Jigsaw Classroom. In: J. Aronson (Ed.), Improving Academic Achievement: Impact of Psychological Factors on Education (pp. 209-225). San Diego, CA, US: Academic Press. doi: 10.1016/B978-012064455-1/50013-0

4. Ballantyne, R., Packer, J. (2009). Introducing a Fifth Pedagogy: Experience-Based Strategies for Facilitating Learning in Natural Environments. Environmental Education Research, 15(2), 243262. doi: $10.1080 / 13504620802711282$

5. Becker, C., Lauterbach, G., Spengler, S., Dettweiler, U., Mess, F. (2017). Effects of Regular Classes in Outdoor Education Settings: A Systematic Review on Students' Learning, Social and Health Dimensions. International Journal of Environmental Research and Public Health, 14(5), 485. doi: 10.3390/ijerph14050485.

6. Bentsen, P., Schipperijn, J., Jensen, F.S. (2013). Green Space as Classroom: Outdoor School Teachers' Use, Preferences and Ecostrategies. Landscape Research, 38(5), 561-575. doi: $10.1080 / 01426397.2012 .690860$

7. Bernstein, J. H. (2015). Transdisciplinarity: A Review of its Origins, Development and Current Issues. Journal of Research Practice, 11(1), R1.

8. Bølling, M., Otte, C.R., Elsborg, P., Nielsen, G., Bentsen, P. (2018). The Association between Education Outside the Classroom and Students' School Motivation: Results from a OneSchool-Year Quasiexperiment. International Journal of Educational Research, 89, 22-35. doi: 10.1016/j.ijcr.2018.03.004

9. Bruinsma, M. (2004). Motivation, Cognitive Processing and Achievement in Higher Education. Learning and Instruction, 14(6), 549-568. doi: 10.1016/j.learninstruc.2004.09.001

10. Chevallard, Y. (1991). La transposición didactica [Didactic transposition]. Buenos Aires: Aique.

11. Freire, P. (2018). Pedagogy of the Oppressed. New York: Bloomsbury Publishing.

12. Giroux, H. (2004). Cultural Studies, Public Pedagogy, and the Responsibility of Intellectuals. Communication and Critical/Cultural Studies, 1(1), 59-79. doi: 10.1080/1479142042000180926.

13. Higgins, P. (2009). Into the Big Wide World: Sustainable Experiential Education for the 21st Century. Journal of Experiential Education, 32(1), 44-60. doi: 10.1177/105382590903200105.

14. Hill, A. (2013). The Place of Experience and the Experience of Place: Intersections Between Sustainability Education and Outdoor Learning. Australian Journal of Environmental Education, 29(1), 18-32. doi: 10.1017/aee.2013.13

15. Immordino-Yang, M. H., Damasio, A. (2007). We Feel, Therefore We Learn: The Relevance of Affective and Social Neuroscience to Education. Mind, Brain and Education, 1(1), 3-10. doi: 10.1111/j.1751-228X.2007.00004.x

16. Kolb, D. A. (1984). Experiential Learning: Experience as the Source of Learning and Development. Englewood Cliffs: Prentice-Hall.

17. Kueffer, C., Forêt, P., Hall, M., Wiedmer, C. (2018). Applying the Environmental Humanities. Gaia, 27(2), 254-256. doi: 10.14512/gaia.27.2.16

18. Kuyper, H., Werf, M., Lubbers, M. (2010). Motivation, Meta-Cognition and Self-Regulation as Predictors of Long Term Educational Attainment. Educational Research and Evaluation: An International Journal on Theory and Practice, 6(3), 181-205. doi: 10.1076/1380-3611\%28200009\%296\%3A3\%3B1-A\%3BFT181.

19. Martín-Ezpeleta, A., Echegoyen-Sanz, Y. (2017). La educación científico-literaria. Ecocrítica y sostenibilidad en la novela Sayonara Sushi de Raül Romeva [Scientific-Literary Education. Ecocriticism and Sustainability in the Novel Sayonara Sushi by Raül Romeva], Letras Hispanas, 13, 270-285.

20. Martín-Ezpeleta, A., Echegoyen-Sanz, Y. (2018). Environmental Humanities in PreService Teachers' Education. Journal of Education Culture and Society, 9(2), 52-64. doi: 10.15503jecs20182.52.64

21. Meyer, D. K., Turner, J.C. (2002). Discovering Emotion in Classroom Motivation Research. Educational Psychologist, 37(2), 107-114. doi: 10.1207/S15326985EP3702_5

22. Nicolescu, B. (2002). Manifesto of Transdisciplinarity. New York: State University of New York Press.

23. O'Connell, T., Potter, T., Curthoys, L., Dyment, J., Cuthbertson, B. (2005). A Call for Sustainability Education in Post-Secondary Outdoor Recreation Programs. International Journal of Sustainability in Higher Education, 6(1), 81-94. doi: 10.1108/14676370510573159 
24. Pekrun, R., Goetz, T., Tits, W., Perry R.P. (2002). Academic Emotions in Students' Self-Regulated Learning and Achievement: a Program of Qualitative and Quantitative Research. Educational Psychologist, 37(2), 91-105. doi: 10.1207/S15326985EP3702_4

25. Symeonidis, V., Schwarz, J. F. (2016). Phenomenon-Based Teaching and Learning Through the Pedagogical Lenses of Phenomenology: The Recent Curriculum Reform in Finland. Forum Oświatowe, 28(2), 31-47. doi: 10.1136/emj.2003.012435.

26. Thompson Klein, J. (2004). Prospects for Transdisciplinarity. Futures, 36(4), 515-526. doi: 10.1016/j.futures.2003.10.007.

27. Ull, À., Piñero, A., Martínez Agut, M. P., Aznar Minguet, P. (2014). Preconcepciones y actitudes del profesorado de Magisterio ante la incorporación en su docencia de competencias para la sostenibilidad [Preconcepcions and Attitudes of Teachers of Teaching School about Incorporated Sustainability Competences in their Teaching]. Enseñanza de las Ciencias, 32(2), 91-112. doi:10.5565/rev/ensciencias.904.

28. Vilches Peña, A., Gil Pérez, D. (2015). Ciencia de la Sostenibilidad: Una nueva disciplina o un nuevo enfoque para todas las disciplinas? [Sustainability Science. A New Discipline or a New Aproach for all Disciplines?]. Revista Iberoamericana de Educación, 69(1), 39-60. doi: 10.35362/ rie691152.

29. Waite, S. (2011). Teaching and Learning Outside the Classroom: Personal Values, Alternative Pedagogies and Standards. Education 3-13, 39(1), 65-82. doi: 10.1080/03004270903206141.

30. Waite, S., Bølling, M., Bentsen, P. (2016). Comparing Apples and Pears? A Conceptual Framework for Understanding Forms of Outdoor Learning through Comparison of English Forest Schools and Danish Udeskole. Environmental Education Research, 22(6), 868-892, doi: 10.1080/13504622.2015.1075193.

31. Wolters, C. A, Pintrich, P. R. (1998). Contextual Differences in Student Motivation and SelfRegulated Learning in Mathematics, English, and Social Studies classrooms. Instructional-Science, 26 (1,2), 27-47. doi: 10.1023/ A:1003035929216. 